\title{
Smoothening agricultural food commodities trade in East Africa Community (EAC): Balancing Tariff Barriers (TBs) and Non- tariff Barriers (NTBs)
}

\author{
Wallace Thoya ${ }^{1 *}$, Prof. Job Lagat, $\mathrm{PhD}^{1}$ and Dr. Symon K. Kiprop, $\mathrm{PhD}^{1}$ \\ 1. Department of Agricultural Economics and Agribusiness Management \\ Egerton University, PO Box 536-20115. Egerton, Kenya \\ * E-mail of the corresponding author: thoyaw@gmail.com
}

This research work was fully funded by the African Economic Research Consortium (AERC)

\begin{abstract}
There is a general belief that removal of barriers to trade would promote increased trade in commodities and particularly food commodities towards improved food security. The East Africa Community (EAC) has made significant headway in eliminating tariff and non-tariff barriers to trade via the Customs Union Protocol. However, information as to whether these policy decisions have contributed to increased availability and access to food commodities is inadequate in literature. This study, therefore, sought to identify the proportion of tariff and nontariff barriers on intra-East Africa Community trade in agricultural food commodities from 1999 to 2014. Trade barrier data was gathered from the Trade Analysis and Information Systems database. Data on prices, production and import levels of food commodities was sourced from Food and Agriculture Organization database and national bureaus of statistics of each EAC country. Results show that despite the tariff lines being relatively higher than duty free lines for most commodities, trade of agricultural food commodities with EAC had been liberalized to a large extent, mainly through more duty-free lines, an attribute that contributed to more trade volumes over the 15year study period. More trade was achieved for products with fewer tariff barriers like coffee. To boost trade the study recommends reducing tariff barriers through increasing the number of duty-free and ad-valorem lines. However, this should be done carefully since it's a major source of foreign exchange to the countries. Further, there is need to reduce distance and time taken to deliver bulk products by improving infrastructure especially road and modern railway networks to bridge the distance gap between non-neighboring countries. Countries also need to ease their custom procedures. For example, Rwanda had among the least profit after tax of 36 percent compared to an average of 67 percent for all the countries. This was mainly attributed to its higher number of customs procedures which were on average five compared to others which had three custom procedures. Lastly, each country needs to specialize more on products they have comparative advantage in producing and exporting.
\end{abstract}

Key words: Trade, Agricultural food commodities, Tariff and non-tariff barriers

DOI: $10.7176 / \mathrm{JESD} / 10-20-13$

Publication date:October $31^{\text {st }} 2019$

\subsection{Background}

Since the 1980's the Bretton Woods Institutions touted trade liberalization as a key solution to achieving food security guided by the concept of comparative advantage (Nguema and Ella, 2014). Trade liberalization was largely viewed as a major determinant of the extent of overall food and nutritional security of a nation by contributing towards total food availability between and among trading partners (Bezuneh and Yiheyis, 2014). The World Bank has spearheaded a number of protocols in support of trade liberalization. For instance, the "Uruguay Round" of 1994 established a food security strategy based on trade under the Multilateral Agreement on Agriculture (MAA) and in the Agreement on Sanitary and Phytosanitary measures. The recommendations of the "Uruguay Round" involved the reduction of barriers to trade and promoted the process of multilateral trade negotiations wherein falls the issues of Regional Economic Communities (RECs) (Nguema and Ella, 2014).

To promote intra-regional trade in commodities, the East African Community (EAC) a Regional Economic Community (REC) comprising of six countries: Kenya, Uganda, Tanzania, Rwanda, Burundi and South Sudan, developed a Customs Union (CU) Protocol enforced in January 2005. One major commitment of the Protocol, in line with easing of intra-EAC commodity trading, was the removal of trade obstacles such as tariff barriers (TBs) and non-tariff barriers (NTBs). A further commitment of the Protocol included: simplifying, standardizing and 
harmonization of trade information and documentation to facilitate trade in goods (East African Community Secretariat [EACS], 2014). Article 13 of the CU Protocol outlined the removal of all existing NTBs and the nonimposition of new ones while article 11 prohibited the use of neither quantitative restrictions on imports, nor all measures having equivalent effects among EAC partner states.

Consequently, the EAC implemented a Common External Tariff (CET) to all non-EAC imports under the auspices of the CU Protocol. Intra-EAC tariffs were thus abolished though Kenya, the largest exporter within EAC was to continue paying duties on its goods entering the other four EAC countries till 2010 (Karugia et al., 2009). However, while there is much effort towards the elimination of TBs and NTBs within the EAC, the partner states still apply some of these measures to protect some key sectors (Okumu and Nyankori, 2010).

With agriculture being the dominant sector in EAC in terms of production and trade, for instance accounting up to $40 \%$ of the total intra-EAC trade (Ouma, 2017), any obstacle to intra-EAC agricultural trade contributes to making agricultural food inaccessible to a vast part of the EAC population. The likely resulting scenario is a case of food insecure communities which besides food inaccessibility, they partake of the problem of nutritional deficiency.

The Protocol of the EAC Customs Union, the EAC Customs Management Act (2004) and the EAC Customs Management Regulations (2006) provided for the steady removal of internal tariffs and implementation of a CET besides other measures related to NTBs elimination. The EAC has performed exemplary well in the area of abolishing intra-EAC tariffs particularly as relates to agricultural commodities (East African Community Secretariat [EACS], 2015). However, certain types of duties or levies have persisted to date thus may have contributed to a slow growth in intra-EAC trade in commodities.

It argued that the existing frameworks for elimination of NTBs within the EAC may not be effective as these barriers continue to exist in spite of having in place the mechanisms for monitoring and eliminating them (Okumu and Nyankori, 2010). While the EAC has been fully committed towards the removal of NTBs, these barriers have continued to contribute to increasing transaction costs and slow growth in intra-EAC trade flows. The Non-Tariff Measures (NTMs) that still exist for instance in Kenya are discriminative, neither transparent nor scientifically based, and generally act as barriers to trade (Nganga, 2014).

Review of literature shows Tariff Measures (TMs) and Non-Tariff Measures (NTMs) have been widely used by the EAC countries. However, when they limit trade amongst the member states, they become barriers. The EAC has made tremendous effort to eliminate TBs and NTBs under different protocols since the removal of these barriers guarantees increased availability and access to nutrition by moving food from surplus to deficit countries within the region. However, information on the number and diversity of TBs and NTBs on food commodities within EAC countries is inadequate. Therefore, this study sought to identify the proportion of Tariff Barriers (TBs) and Non-Tariff Barriers (NTBs) applied by each country to each other for each agricultural food commodity traded in the East Africa Community.

\subsection{Theory and conceptualization}

The existence of TBs, NTBs and Trade Liberalization strategies on intra-regional trade in food commodities as discussed in this study used the Ricardian trade theory of comparative advantage under the assumptions of perfect competition and the Heckscher-Ohlin (H-O) theorem (Leamer, 1995; Morrow, 2010). The Ricardian comparative advantage theory proposed that differences in productivity and opportunity costs of production between countries form the underlying reasons why it is advantageous for countries to engage in trade.

Morrow, (2010) argues that the Heckscher-Ohlin (H-O) theorem discusses about the pattern of trade, based on nations' differing factor endowments and the factor requirements of different kinds of goods. The theory highlights that trade occurs because the cost of labor relative to that of capital is lower in the labor-abundant country, implying that the price ratio of labour-intensive goods to capital intensive goods is lower in the labor abundant country than in the capital-abundant country. Under competitive free market conditions, trade maximizes potential economic welfare internationally, by creating a situation where no country could be made better off without another being made worse off.

\subsection{Study area and methodology}

This study considered five out of six countries within the Eastern African Region: Burundi, Kenya, Rwanda, Uganda and Tanzania. The study excluded South Sudan as it was the newest member having been accepted into the EAC in 2016 and bears no adequate data of trade flow and trade policy imposed affecting or affected by the other five EAC member states.

Secondary data was obtained of average annual TBs and NTBs for all food commodities traded within EAC for all five (5) EAC countries. This study used data from the UNCTAD TRAINS Database. The UNCTAD TRAINS 
Database is a stock of bilateral TBs, NTBs and trade flow between and among countries and regions in the world. The observations represented bilateral trade of each country with each other making it four (4) trade observations for each of the five (5) countries annually. This was done for sixteen (16) time periods (Year 1999 to Year 2014). Therefore, the study used 320 observations in the analysis.

To analyze data to determine the proportion of Tariff Barriers (TBs) and Non-tariff Barriers (NTBs) applied by each EAC country to each other for all the food commodities, descriptive statistics such as the average and number were used. Tabular analysis was used to compare the average TBs and NTBs for each county to the other for each food commodity involved for the sixteen (16) years. In particular, the five countries' average weighted or unweighted tariff rates for the food commodities in the ISIC Agricultural sector were calculated. This analysis helped to determine the average number and type of TBs and NTBs applied by each country to each other within Eastern Africa to each food commodity being assessed. The variables used in the analysis are as shown in Table 1.

Table 1: Description of variables and their measurement

\begin{tabular}{|c|c|c|}
\hline Variable & Variable description & Measurement \\
\hline Simple Average & Simple average tariff rates of included products (in percentage) & Percent \\
\hline Weighted Average & Weighted average tariff rates & Number \\
\hline Min Rate & $\begin{array}{l}\text { Returns the lowest tariff rate at the tariff line level within the product } \\
\text { category (in percentage) }\end{array}$ & Percent \\
\hline Max Rate & $\begin{array}{l}\text { Returns the highest tariff value at the tariff line level within the } \\
\text { product category (in percentage) }\end{array}$ & Percent \\
\hline Trade Value & $\begin{array}{l}\text { Value of imports of a specific product from the East Africa } \\
\text { Community (EAC) }\end{array}$ & $\begin{array}{l}\text { US Dollars (in thousand } \\
\text { US \$) }\end{array}$ \\
\hline No. of Tariff Lines & Total number of tariff lines within the product category & Number \\
\hline $\begin{array}{l}\text { No. of Duty-free } \\
\text { Lines }\end{array}$ & $\begin{array}{l}\text { Number of tariff lines within the product category for which the rates } \\
\text { are free }\end{array}$ & Number \\
\hline $\begin{array}{l}\text { No. of Dutiable } \\
\text { Lines }\end{array}$ & $\begin{array}{l}\text { Number of tariff lines within the product category for which the rates } \\
\text { are in ad valorem }\end{array}$ & Number \\
\hline
\end{tabular}

\subsection{Results and discussion}

The analysis used a panel dataset of 16 years (1999-2014) of exports for ten selected agricultural food commodities traded within the East African Community (EAC) considering Kenya, Uganda, Tanzania, Burundi and Rwanda. Within the results and discussion, the first acronym of the countries involved (for example KEN_UGA), represents the importing country while the second acronym is the exporter for example, KEN_UGA implies Kenya imported from Uganda.

\subsubsection{Proportion of Tariff Barriers (TBs) for EAC countries in relation to each other} Live animals

Live animals were some of the most traded commodities in Eastern Africa. The average percentage of tariff rates across countries varied from $0.25 \%$ (Uganda to Rwanda) to $12.5 \%$ (Rwanda to Tanzania) (Error! Reference source not found.2). The tariff rates were different from one country to another and this influenced the number of live animals traded. As a result, the trade value of the commodity varied from USD 1,590 (Rwanda to Tanzania) to USD 1,137,854 (Uganda to Rwanda). This implies that the Rwanda took advantage of the demand in Uganda and imposed a higher tariff rate resulting in high revenues. The average tariff rates for imports to Burundi were approximately $5 \%$ depending on the source country (that is, Burundi - Kenya $=5.667 \%$ and Burundi - Uganda $=$ $4.417 \%$ ). Burundi had the highest imports of live animals from Uganda (USD 464,888) which could be influenced by bilateral trade agreements between the two countries where Burundi further opened its borders from the year 2010 to allow free movement of its products between Burundi and Uganda through Rwanda after Burundi joined the EAC in the year 2007 and the move to liberalize trade in line with the Common Market for Eastern and Southern Africa (COMESA) free trade area. 
Similarly, Rwanda imported animals mostly from Uganda and had the lowest tariff rates in the whole region. On the other hand, there were minimal live animal imports from Eastern African countries to Kenya despite the slightly low tariff rates of about $2 \%$. Tanzania used high tariff rates $(12.5 \%)$ to bar live animal imports from Rwanda. However, the country had low tariff rates of about 2.5\% between other countries which led to high import from Kenya (USD 521,573). Further, Uganda had some of the lowest tariff rates ranging between $0.5 \%$ to $1.6 \%$ and the largest live animal business partner was Kenya.

The trade between the countries was further influenced by the number of duty-free tariff lines within the product category. All countries had at least one tariff line with its trading partners, but the lines were highest between Tanzania and Kenya, Uganda and Kenya and Rwanda and Uganda. As a result, the countries with high number of duty-free tariff lines registered the highest live animal imports. This was further reflected by the number of dutyfree lines which were also highest in these countries. The results also reveal that the average number of lines with ad-valorem rates (No. of dutiable lines in Table 3) was at least one in several years.

Ad-valorem refers to the tariff imposed on the goods imported based on the value of the commodities. Tariffs are generally known to have a varying impact on different stakeholders involved in the international trade. This includes the importing country consumers and producers and the exporting country producers and consumers. The ad-valorem rates were highest between Rwanda and Tanzania (1.000). In addition, the countries experienced a low trade value of about USD 389 as compared to other countries with a low tariff rates. This implies that because of the high tariffs, consumers of the product in the importing country (Rwanda) experienced reduced well-being because of the trade tariff. Besides, the rise in price of both domestic and imported goods reduces amount of consumer surplus in the market. Nonetheless, producers of substitute products in Rwanda (importing country) may have experienced an increase in well-being as result of the trade tariff. However, the public (consumers) who are most adversely by the tariffs, purchase relatively lesser imported goods, an issue that explains the low rate of importation of live animals into Rwanda as shown in Table 2. Overall, Rwanda was the highest importer of live animals followed by Tanzania, Burundi, Uganda and finally Kenya from the Eastern Africa region. Moreover, Uganda was the largest exporter of live animals in the region with most exports going to Burundi and Rwanda.

Table 2: The level tariff barriers and trade value of live animals among EAC countries (1999-2014)

\begin{tabular}{|c|c|c|c|c|c|}
\hline 1 & $\begin{array}{r}\text { Simple Average } \\
\text { (tariff rate)- (in } \\
\text { percentage) }\end{array}$ & $\begin{array}{l}\text { Trade Value (in } \\
\text { thousand USD) }\end{array}$ & $\begin{array}{r}\text { No. of Tariff } \\
\text { Lines }\end{array}$ & $\begin{array}{l}\text { No. of Duty- } \\
\text { free Lines }\end{array}$ & $\begin{array}{r}\text { No. of Dutiable (ad } \\
\text { valorem) Lines }\end{array}$ \\
\hline BDI_KEN & 5.667 & 9.111 & 2.444 & 1.556 & 0.444 \\
\hline BDI_RWA & & 18.433 & 3.000 & 3.000 & \\
\hline BDI_TZA & & 4.720 & 1.000 & 1.000 & \\
\hline BDI_UGA & 4.417 & 464.888 & 4.083 & 2.667 & 0.500 \\
\hline KEN_RWA & & 0.097 & 1.000 & 1.000 & \\
\hline KEN_TZA & 1.364 & 39.811 & 3.818 & 3.545 & 0.273 \\
\hline KEN_UGA & 2.308 & 12.519 & 3.231 & 2.846 & 0.385 \\
\hline RWA_KEN & & 3.374 & 2.500 & 2.500 & \\
\hline RWA_TZA & 5.000 & 0.389 & 1.000 & & 1.000 \\
\hline RWA_UGA & 0.250 & $1,137.854$ & 8.750 & 7.125 & 0.500 \\
\hline \multicolumn{6}{|l|}{ TZA_BDI } \\
\hline TZA_KEN & 2.595 & 521.573 & 9.083 & 7.083 & 0.500 \\
\hline TZA_RWA & 12.500 & 1.590 & 1.000 & 0.500 & 0.500 \\
\hline TZA_UGA & 2.500 & 23.337 & 2.333 & 2.167 & 0.167 \\
\hline UGA_BDI & & 27.785 & 1.000 & 1.000 & \\
\hline UGA_KEN & 1.480 & 247.384 & 8.000 & 6.000 & 0.333 \\
\hline UGA_RWA & 0.500 & 4.168 & 1.600 & 1.400 & 0.200 \\
\hline UGA_TZA & 1.600 & 5.934 & 1.900 & 1.500 & 0.400 \\
\hline
\end{tabular}

Key: No. - Number, BDI - Burundi, RWA - Rwanda, KEN - Kenya, TZA - Tanzania, UGA - Uganda 


\section{Meat and edible meat offal}

The importation of meat and edible meat offal has been increasing in the Eastern Africa economic region with Tanzania being the largest importer of the product followed by Uganda, Burundi, Rwanda and Kenya. Kenya was however the largest exporter of meat and edible meat offal in the region with the highest exports going to Tanzania and Uganda between 1999 and 2014 (

Table ). This could be attributed to Kenya's climatic condition favoring beef production. The tariff rates for the product varied from $0.4 \%$ (Uganda to Rwanda) to $6 \%$ (Tanzania to Uganda). However, the largest imports were to Tanzania's from Kenya (USD 2,706,823) despite the tariff rates of approximately $3 \%$ which was considerably high. Burundi mainly imports meat and edible meat offal from Uganda at tariff rates of (4\%) while Rwanda and Uganda import from Kenya at rates of (1.5\% and $2 \%)$ respectively.

The results further reveal that across the years of 1999-2014, Tanzania-Kenya had on average the highest number of tariff lines (13) where 9 were duty-free lines while Rwanda-Uganda and Uganda-Kenya had approximately 6 tariff lines. The tariff lines were high in between Kenya which is the exporting country and the partner country, Tanzania, with the highest imports. Furthermore, there was at least one ad-valorem tariff line between the major importing countries and their trading partners in the meat and edible meat offal product.

From Table 3, it is evident most of the tariff lines Tanzania had imposed on Kenya when importing meat and edible meat offal were duty-free (on average 9). Duty-free tariff lines are meant to increase trade between the countries. This attracted huge trade volumes of meat and edible meat offal from Kenya to Tanzania making the traded value the highest in the region USD 2,706,823. Moreover, imposing trade barriers on the commodity implies that Tanzania was protecting meat producers from cheap meat products from Kenya. However, the huge trade value indicates a scarcity of the commodity in Tanzania, hence Kenya was still getting market

Table 3: Averages of tariff barriers and trade value of meat and edible meat offal averages (1999-2014)

\begin{tabular}{|c|c|c|c|c|c|}
\hline 2 & $\begin{array}{r}\text { Simple Average } \\
\text { (tariff rate)- (in } \\
\text { percentage) }\end{array}$ & $\begin{array}{r}\text { Trade Value } \\
\text { (in thousand } \\
\text { USD) }\end{array}$ & $\begin{array}{l}\text { No. of } \\
\text { Tariff } \\
\text { Lines }\end{array}$ & $\begin{array}{l}\text { No. of Duty- } \\
\text { free Lines }\end{array}$ & $\begin{array}{l}\text { No. of Dutiable (ad } \\
\text { valorem) Lines }\end{array}$ \\
\hline \multicolumn{6}{|l|}{ BDI_KEN } \\
\hline BDI_RWA & & 2.122 & 2.000 & 2.000 & \\
\hline \multicolumn{6}{|l|}{ BDI_TZA } \\
\hline BDI_UGA & 4.111 & 139.824 & 3.778 & 1.444 & 0.444 \\
\hline KEN_TZA & & 0.189 & 1.000 & 1.000 & \\
\hline KEN_UGA & & 4.235 & 2.000 & 2.000 & \\
\hline \multicolumn{6}{|l|}{ RWA_BDI } \\
\hline RWA_KEN & 1.500 & 64.972 & 4.500 & 4.200 & 0.100 \\
\hline RWA_TZA & & 0.838 & 1.000 & 1.000 & \\
\hline RWA_UGA & 0.429 & 4.176 & 6.000 & 5.000 & 0.143 \\
\hline TZA_KEN & 2.821 & $2,706.823$ & 13.083 & 9.083 & 0.417 \\
\hline TZA_UGA & & 186.678 & 3.000 & 3.000 & \\
\hline UGA_KEN & 2.000 & 354.150 & 6.133 & 3.133 & 0.333 \\
\hline \multicolumn{6}{|l|}{ UGA_RWA } \\
\hline UGA_TZA & 6.000 & 1.706 & 1.000 & & 1.000 \\
\hline
\end{tabular}

Key: No. - Number, BDI - Burundi, RWA - Rwanda, KEN - Kenya, TZA - Tanzania, UGA - Uganda

Fish and crustaceans, molluscs and other aquatic invertebrates

Rwanda was the largest importer of fish among EAC countries between 1999 and 2014 attributed to its landlocked status and the lack of large water bodies for fishing (

Table 4). Further, most of fish in the region was exported by Tanzania which could be attributed to the access to large water bodies for fishing including Lakes Tanganyika and Victoria as well as the Indian Ocean. Another major 
factor that could have influenced the high exports from Tanzania is its centrality to the importing countries since it shares a border with the largest importers among them Rwanda and Kenya. The importation of fish by Kenya could be influenced by large populations demanding the product and lack of self-sufficiency. It is approximated Kenya consumed 195,206 tonnes of fresh water fish in 2014 and imports approximately 5,900 tonnes annually (Farm Africa, 2016). The tariff rates between the countries varied from $0.7 \%$ to $8 \%$. The tariff rates for fish products between countries were relatively higher compared to those of meat products. Burundi imposed the highest rates $(8 \%)$ for fish imports from Kenya and a lower rate $(4.7 \%)$ from Uganda. Tanzania seemed to protect its fish industry by slapping a $6.25 \%$ tariff on Uganda which was relatively higher than the $2 \%$ Uganda charged Tanzania. This effectively discouraged fish flow from Uganda. However, Tanzania imposed lower rates on fish from Kenya (2.68\%) which were relatively low as compared to $5.36 \%$ by Kenya from Tanzania. Notwithstanding, the high demand of fish from Kenya encouraged their importation by Tanzania.

Rwanda-Uganda had the highest number of tariff lines (22) among them 18 were duty-free which implied a large flow of fish to Rwanda. Further, Rwanda had 10 tariff lines from Kenya all of which were free and yet the country registered low imports from Kenya probably because of the perishability of fish and the long distance between the two countries.

A similar scenario of all duty-free tariff lines on fish products was between Burundi and Rwanda which also recorded low imports. This could be attributed to low quantity of fish in Rwanda since the geographical distance between the countries is relatively shorter compared to countries like Kenya. At least $75 \%$ of all tariff line across the Eastern African countries on fish, crustaceans, molluscs and other aquatic invertebrates' imports were dutyfree.

However, Table 4 also reveals a different scenario, where there is a high demand of fish from Tanzania in Kenya (USD 864,325) compared to those from Uganda (USD 223,860) despite the lower tariff rates from Uganda (3\%) compared to $5 \%$ in Tanzania. This could be attributed to customer preferences and probably unaccounted fish captured and sold by fishermen from both countries on Lake Victoria which is a shared water body.

Table 4: Averages of tariff barriers and trade value of fish and crustaceans, molluscs and other aquatic invertebrates averages (1999-2014)

\begin{tabular}{|c|c|c|c|c|c|}
\hline 3 & $\begin{array}{r}\text { Simple Average } \\
\text { (tariff rate)- (in } \\
\text { percentage) }\end{array}$ & $\begin{array}{l}\text { Trade Value (in } \\
\text { thousand USD) }\end{array}$ & $\begin{array}{r}\text { No. of } \\
\text { Tariff } \\
\text { Lines }\end{array}$ & $\begin{array}{l}\text { No. of Duty- } \\
\text { free Lines }\end{array}$ & $\begin{array}{r}\text { No. of Dutiable } \\
\text { (ad valorem) } \\
\text { Lines }\end{array}$ \\
\hline BDI_KEN & 8.000 & 0.554 & 1.000 & & 1.000 \\
\hline BDI_RWA & & 4.973 & 1.600 & 1.600 & \\
\hline BDI_TZA & 5.000 & 140.944 & 4.000 & 3.556 & 0.444 \\
\hline BDI_UGA & 4.727 & 33.511 & 5.182 & 4.727 & 0.455 \\
\hline KEN_TZA & 5.357 & 864.325 & 7.214 & 5.143 & 0.357 \\
\hline KEN_UGA & 2.500 & 223.860 & 5.917 & 5.500 & 0.167 \\
\hline RWA_BDI & & 116.734 & 8.571 & 8.571 & \\
\hline RWA_KEN & & 51.406 & 10.000 & 10.000 & \\
\hline RWA_TZA & 3.444 & $3,044.380$ & 9.778 & 7.889 & 0.333 \\
\hline RWA_UGA & 0.738 & $1,608.529$ & 21.500 & 18.125 & 0.375 \\
\hline TZA_KEN & 2.681 & 64.991 & 3.917 & 3.000 & 0.333 \\
\hline TZA_UGA & 6.250 & 2.967 & 1.250 & 1.000 & 0.250 \\
\hline UGA_KEN & 2.000 & 238.959 & 10.933 & 8.867 & 0.333 \\
\hline UGA_RWA & 6.000 & 0.130 & 1.000 & & 1.000 \\
\hline UGA_TZA & 2.000 & 255.510 & 10.133 & 7.400 & 0.333 \\
\hline
\end{tabular}

Key: No. - Number, BDI - Burundi, RWA - Rwanda, KEN - Kenya, TZA - Tanzania, UGA - Uganda

Dairy produce, birds' eggs, natural honey, edible products of animal origin, not elsewhere specified or included 
Kenya was both the largest importer and exporter of the dairy produce, eggs and honey in East Africa region between 1999 and 2014 (

Table 5). Kenya also had the highest tariff rates (20\%) specifically against Tanzania on the import of the dairy produce, eggs and natural honey. Since it produces similar products, such rates become necessary to protect its local industry. A similar pattern was observed for trade between Burundi and Uganda where the latter imposed high rates $(12 \%)$ on dairy produce, eggs and honey from Burundi with the intention of reducing their entry and protection of its local industry. The rest of the region had varying tariff rates ranging from $0.5 \%$ to $12 \%$

The results also reveal that the number of tariff lines varied across the countries ranging from 2 to 18 lines. However, majority of these tariffs were duty-free lines with each country having an occasional ad valorem line with the trading partners.

Table 5: Averages of tariff barriers and trade value of dairy produce; birds' eggs; natural honey; edible products of animal origin, not elsewhere specified or included averages (1999-2014)

\begin{tabular}{|c|c|c|c|c|c|}
\hline 4 & $\begin{array}{r}\text { Simple Average } \\
\text { (tariff rate)- (in } \\
\text { percentage) }\end{array}$ & $\begin{array}{r}\text { Trade Value } \\
\text { (in thousand } \\
\text { USD) }\end{array}$ & $\begin{array}{l}\text { No. of } \\
\text { Tariff } \\
\text { Lines }\end{array}$ & $\begin{array}{r}\text { No. of } \\
\text { Duty-free } \\
\text { Lines }\end{array}$ & $\begin{array}{r}\text { No. of Dutiable } \\
\text { (ad valorem) } \\
\text { Lines }\end{array}$ \\
\hline BDI_KEN & 5.000 & 521.019 & 6.571 & 4.571 & 0.571 \\
\hline BDI_RWA & 2.000 & 24.605 & 2.250 & 2.000 & 0.250 \\
\hline BDI_TZA & 2.000 & 6.552 & 5.000 & 3.600 & 0.600 \\
\hline BDI_UGA & 3.700 & 229.047 & 11.300 & 8.000 & 0.800 \\
\hline KEN_TZA & 20.243 & 90.736 & 2.385 & 1.462 & 0.154 \\
\hline KEN_UGA & 9.589 & $5,197.310$ & 5.800 & 5.067 & 0.400 \\
\hline RWA_BDI & & 4.119 & 8.125 & 8.125 & \\
\hline RWA_KEN & 2.615 & 89.464 & 10.385 & 9.462 & 0.308 \\
\hline RWA_TZA & 6.600 & 247.975 & 3.500 & 2.200 & 0.500 \\
\hline RWA_UGA & 2.100 & 541.267 & 12.308 & 9.077 & 0.615 \\
\hline TZA_KEN & 5.384 & $2,991.379$ & 15.750 & 10.083 & 0.833 \\
\hline \multicolumn{6}{|l|}{ TZA_RWA } \\
\hline TZA_UGA & 0.500 & 331.167 & 6.100 & 6.000 & 0.100 \\
\hline UGA_BDI & 12.000 & 17.511 & 1.000 & & 1.000 \\
\hline UGA_KEN & 3.305 & $1,859.160$ & 18.600 & 8.400 & 0.867 \\
\hline UGA_RWA & 2.400 & 1.509 & 1.800 & 1.400 & 0.400 \\
\hline UGA_TZA & 0.545 & 12.368 & 2.455 & 2.364 & 0.091 \\
\hline
\end{tabular}

Key: No. - Number, BDI - Burundi, RWA - Rwanda, KEN - Kenya, TZA - Tanzania, UGA - Uganda

\section{Products of animal origin not elsewhere specified or included}

Few EAC countries traded with products of animal origin such as human hair; pigs, guts, bladders and stomachs of animals; bones and horn-cores; ivory, tortoise shell and coral and similar materials (Error! Not a valid bookmark self-reference.). However, Kenya was the highest importer of these products mostly from Tanzania valued at (USD 2,076,993) which may be because of the high local demand. Further the tariff rates for these animal products averaged $2.5 \%$ between Kenya and Tanzania compared to between $0.67 \%$ and $1.45 \%$ from the rest of EAC countries. The results reveal the unpopularity of these animal products across Eastern Africa with majority of countries trading at an average value of less that USD 100,000 of the commodity.

The tariff rate on these products between Burundi and Kenya was the highest at $17.5 \%$ which could be a measure of curbing trafficking of wildlife parts such as ivory from Burundi. The number of tariff line for the animal products averaged at 3 for most of the countries except for Kenya-Tanzania and Kenya-Uganda that had an average of about 7 lines. However, about $90 \%$ of the lines were duty-free. There was also at least one ad valorem line for the animal products between the countries. 
Table 6: Averages of tariff barriers and trade value of products of animal origin, not elsewhere specified or included averages (1999-2014)

\begin{tabular}{|c|c|c|c|c|c|}
\hline 5 & $\begin{array}{r}\text { Simple Average } \\
\text { (tariff rate)- (in } \\
\text { percentage) }\end{array}$ & $\begin{array}{l}\text { Trade Value (in } \\
\text { thousand USD) }\end{array}$ & $\begin{array}{l}\text { No. of } \\
\text { Tariff } \\
\text { Lines }\end{array}$ & $\begin{array}{r}\text { No. of } \\
\text { Duty-free } \\
\text { Lines }\end{array}$ & $\begin{array}{r}\text { No. of Dutiable } \\
\text { (ad valorem) } \\
\text { Lines }\end{array}$ \\
\hline BDI_KEN & 17.500 & 0.513 & 1.000 & & 1.000 \\
\hline \multicolumn{6}{|l|}{ BDI_RWA } \\
\hline BDI TZA & & 10.097 & 3.000 & 3.000 & \\
\hline \multicolumn{6}{|l|}{ BDI_UGA } \\
\hline \multicolumn{6}{|l|}{ KEN_RWA } \\
\hline KEN_TZA & 2.778 & $2,076.993$ & 3.333 & 2.167 & 1.167 \\
\hline KEN_UGA & & 66.392 & 3.111 & 3.111 & \\
\hline RWA_KEN & & 12.043 & 3.143 & 3.143 & \\
\hline RWA_TZA & 0.714 & 3.421 & 3.000 & 2.571 & 0.429 \\
\hline RWA_UGA & 0.143 & 2.491 & 7.286 & 5.714 & 0.571 \\
\hline \multicolumn{6}{|l|}{ TZA_BDI } \\
\hline TZA_KEN & 1.000 & 8.464 & 1.800 & 1.400 & 0.400 \\
\hline \multicolumn{6}{|l|}{ TZA_RWA } \\
\hline \multicolumn{6}{|l|}{ TZA_UGA } \\
\hline UGA_BDI & 1.000 & 0.872 & 2.000 & 1.750 & 0.250 \\
\hline UGA_KEN & 1.451 & 44.745 & 6.533 & 5.067 & 0.533 \\
\hline UGA_RWA & 0.667 & 0.403 & 3.667 & 3.667 & \\
\hline UGA_TZA & & 100.349 & 3.583 & 3.250 & 0.167 \\
\hline
\end{tabular}

Key: No. - Number, BDI - Burundi, RWA - Rwanda, KEN - Kenya, TZA - Tanzania, UGA - Uganda

Live trees and other plants, bulbs, roots and the like, cut flowers and ornamental foliage

Kenya was one of the largest importers of live trees and other plants in Eastern Africa and it was also one of the largest exporters of the same products (

Table ). This may be because, Kenya's horticulture sector is highly developed allowing the exportation of items such as cut flowers and ornamental foliage to all EAC countries of Uganda, Tanzania and Rwanda.

The trade of these commodities with Burundi from any of the Eastern African country was minimal which could be because of its location near the equatorial rain forest implying importation of trees would be minimal. It is also evident that there were high tariff rates between Burundi and Kenya on the items $(11.67 \%)$ which could also be a major contributing factor to the low level of trade.

The rest of the EAC countries enjoyed tariff rates for the commodity varying between $0.25 \%$ and $1.5 \%$ apart from Kenya and Uganda (2.56\%). This high rate between Kenya and Uganda could be attributed to Kenya's effort to shield its domestic horticulture industry specifically on flowers and ornamental foliage from external markets. Further, the high level of exports from Kenya to other countries could be attributed to the high levels of advancement in the horticulture sector. This is also associated with the fact that despite the high number of tariff lines from Kenya to other Eastern African countries ranging from 5 to 8, trade of live tree and other plants are duty-free.

It is important to acknowledge that ad valorem (dutiable) lines had an influence on the trade value of the trading countries. Countries will low dutiable lines seemed to import more as compared to their counterparts with higher tariffs. Table 8 shows that Uganda and Kenya have set high ad valorem lines each other, at 0.333 and 0.429 respectively, probably to protect their local producers. Nonetheless, despite the high rate, Uganda was the second largest importer of live trees and other plants; bulbs, roots and the like; cut flowers and ornamental foliage in the East African region (USD 381,556). This implies that local consumers for the product were finding Kenya's products to be cheaper and probably better quality besides the many dutiable tariffs imposed. Moreover, the proximity between the two countries could be a factor. Besides, Kenya also remains to be the lead exporter of cut 
flowers to the European Union with a highest market share of 38\% (Kenya Trade Organization, 2018). This depicts that Kenya's cut flowers are of high quality and competitive as per global standards.

Table 7: Averages of tariff barriers and trade value of live trees and other plants; bulbs, roots and the like; cut flowers and ornamental foliage averages (1999-2014)

\begin{tabular}{|c|c|c|c|c|c|}
\hline 6 & $\begin{array}{r}\text { Simple Average } \\
\text { (tariff rate)- (in } \\
\text { percentage) }\end{array}$ & $\begin{array}{l}\text { Trade Value (in } \\
\text { thousand USD) }\end{array}$ & $\begin{array}{l}\text { No. of } \\
\text { Tariff } \\
\text { Lines }\end{array}$ & $\begin{array}{r}\text { No. of } \\
\text { Duty-free } \\
\text { Lines }\end{array}$ & $\begin{array}{r}\text { No. of Dutiable } \\
(\text { ad valorem) } \\
\text { Lines }\end{array}$ \\
\hline BDI_KEN & 11.667 & 7.817 & 1.333 & 0.667 & 0.667 \\
\hline \multicolumn{6}{|l|}{ BDI_RWA } \\
\hline BDI_TZA & 1.250 & 0.076 & 1.000 & 0.750 & 0.250 \\
\hline BDI_UGA & 0.250 & 0.119 & 2.500 & 2.250 & 0.250 \\
\hline KEN_RWA & & 1.009 & 1.000 & 1.000 & \\
\hline KEN_TZA & 1.500 & 470.562 & 2.700 & 2.600 & 0.100 \\
\hline KEN_UGA & 2.560 & 41.744 & 2.714 & 2.000 & 0.429 \\
\hline RWA_KEN & 0.500 & 350.015 & 4.800 & 4.700 & 0.100 \\
\hline RWA_TZA & 1.000 & 0.148 & 1.000 & 0.800 & 0.200 \\
\hline RWA_UGA & 0.626 & 62.623 & 7.778 & 6.333 & 0.222 \\
\hline \multicolumn{6}{|l|}{ TZA_BDI } \\
\hline TZA_KEN & 0.521 & 172.508 & 5.167 & 4.833 & 0.167 \\
\hline \multicolumn{6}{|l|}{ TZA_RWA } \\
\hline TZA_UGA & & 10.179 & 1.625 & 1.625 & \\
\hline \multicolumn{6}{|l|}{ UGA_BDI } \\
\hline UGA_KEN & 0.575 & 381.556 & 7.067 & 6.133 & 0.333 \\
\hline UGA_RWA & & 14.409 & 1.000 & 1.000 & \\
\hline UGA_TZA & & 8.349 & 1.500 & 1.500 & \\
\hline
\end{tabular}

Key: No. - Number, BDI - Burundi, RWA - Rwanda, KEN - Kenya, TZA - Tanzania, UGA - Uganda

Edible vegetables and certain roots and tubers

Kenya and Rwanda were the leading importers of edible vegetables in the East Africa region in the years of 1999 to 2014 (Error! Not a valid bookmark self-reference.). This could be because of demand that the local production could not meet. The results reveal that Uganda is the main exporter of edible vegetables in EAC which could be attributed to the favorable environmental conditions. Contrary, it was evident that Kenya despite being a net importer, it imposed the highest tariff rates of about $10 \%$ which could be meant to protect the local vegetable sector. Burundi also had high tariff rates of between $4 \%$ and $12 \%$. The rest of the countries that is Tanzania, Uganda and Rwanda had low import tariff rates for edible vegetables ranging from $0.4 \%$ to $2.5 \%$.

Countries with few ad valorem lines for edible vegetables and certain roots and tubers like Kenya attracted huge imports from her trade partners like Uganda (0.333) and Tanzania (0.357) at USD 5,472,149 and 2,462,069. The trade values are relatively high compared a country like Burundi whose traded value with Kenya was USD 5,484 but with higher average ad valorem of 1.333 . The low ad valorem from Kenya to her trading partners could imply a move to attract more imports given a high local demand and lack of self-sufficiency. This could be because of a high demand for green vegetables in Kenya, a country where ugali, whose accompaniment is mainly vegetables, is one of the main staple foods. Kenya's vegetable products Import Dependency Ratio (IDR) rose from $26 \%$ in 2013 to $46.9 \%$ in 2017 attributable to a rise in imports due to food deficits experienced in the country (KNBS 2018). This is despite the rise in value of locally produced and marketed vegetables from USD 229,233,000 in 2013 to $240,646,000$ in 2017 (KNBS, 2018). 
Table 8: Averages of tariff barriers and trade value of edible vegetables and certain roots and tubers averages (1999-2014).

\begin{tabular}{lrrrrr}
\hline 7 & $\begin{array}{r}\text { Simple Average } \\
\text { (tariff rate) } \text { (in } \\
\text { percentage) }\end{array}$ & $\begin{array}{r}\text { Trade Value } \\
\text { (in thousand } \\
\text { USD) }\end{array}$ & $\begin{array}{r}\text { No. of } \\
\text { Tariff } \\
\text { Lines }\end{array}$ & $\begin{array}{r}\text { No. of Duty- } \\
\text { free Lines }\end{array}$ & $\begin{array}{r}\text { No. of Dutiable }(\text { ad } \\
\text { valorem) Lines }\end{array}$ \\
\hline BDI_KEN & 11.667 & 5.484 & 1.667 & 0.333 & 1.333 \\
BDI_RWA & 4.375 & 871.087 & 10.375 & 9.375 & 0.500 \\
BDI_TZA & 5.182 & 315.502 & 5.000 & 2.909 & 0.909 \\
BDI_UGA & 4.083 & 239.961 & 7.667 & 5.417 & 0.833 \\
KEN_RWA & & 0.010 & 1.000 & 1.000 & \\
KEN_TZA & 10.357 & $2,462.069$ & 9.786 & 7.571 & 0.357 \\
KEN_UGA & 9.667 & $5,472.149$ & 6.600 & 4.667 & 0.333 \\
RWA_BDI & & 389.458 & 20.571 & 20.571 & 0.615 \\
RWA_KEN & 0.923 & $1,179.386$ & 15.538 & 14.077 & 0.556 \\
RWA_TZA & 1.302 & 740.568 & 12.222 & 9.667 & 0.667 \\
RWA_UGA & 0.796 & $1,761.633$ & 32.222 & 25.111 & 0.333 \\
TZA_KEN & 2.526 & 311.278 & 9.750 & 8.750 & \\
TZA_RWA & & 68.708 & 3.200 & 3.200 & 0.100 \\
TZA_UGA & 0.400 & 373.736 & 3.700 & 3.200 & 0.333 \\
UGA_BDI & & & & & 0.333 \\
UGA_KEN & 2.000 & 480.516 & 28.267 & 18.600 & 0.333 \\
UGA_RWA & 1.778 & 58.781 & 2.444 & 1.778 & \\
UGA_TZA & 2.000 & 356.679 & 6.800 & 5.467 &
\end{tabular}

Key: No. - Number, BDI - Burundi, RWA - Rwanda, KEN - Kenya, TZA - Tanzania, UGA - Uganda

The tariff lines in the East Africa region for edible vegetables ranged from 2 to 32 varying from one country to another but Rwanda had the highest number of import tariff lines. Moreover, the highest proportion of the tariff line for edible vegetables were duty-free as evidenced in the results. It was also revealed that at least each country had an ad valorem line of the commodity which could be attributed to efforts of each country to meet its own demand.

\section{Edible fruits and nuts, peel of citrus fruit or melons}

The largest importer of edible fruits and nuts in the EAC between 1999 and 2014 was Rwanda while the largest exporter was Tanzania ( 
Table 9). Tanzania's agro-ecological environment has allowed for a well-established fruit production system while Rwanda has high demand for the products. However, to protect the local fruit production in Kenya, high tariff rates were imposed on Tanzania (5.7\%). The rest of the region had tariff rates ranging from $0.25 \%$ and $2.5 \%$.

It is also evident from the results (Table 10) that Rwanda had high imports of edible fruits, nuts, peel of citrus or melons which could be explained by the low tariff rates (less than 1\%) to encourage importation of the commodity to the country. The number of tariff lines for the trade commodities in the region ranged from 1 to 32 . However, most of the tariff lines were duty-free with a few ad valorem lines across the period. This indicates a relatively liberalized trade of edible fruits, nuts, peel of citrus or melons across the EAC region probably because all the countries produced the products and mainly exported surplus or import to meet deficits. 
Table 9: Averages of tariff barriers and trade value of edible fruit and nuts; peel of citrus fruit or melons averages (1999-2014)

\begin{tabular}{|c|c|c|c|c|c|}
\hline 8 & $\begin{array}{l}\text { Simple Average } \\
\text { (tariff rate)- (in } \\
\text { percentage) }\end{array}$ & $\begin{array}{r}\text { Trade Value } \\
\text { (in thousand } \\
\text { USD) }\end{array}$ & $\begin{array}{l}\text { No. of } \\
\text { Tariff } \\
\text { Lines }\end{array}$ & $\begin{array}{l}\text { No. of Duty- } \\
\text { free Lines }\end{array}$ & $\begin{array}{r}\text { No. of Dutiable } \\
\text { (ad valorem) } \\
\text { Lines }\end{array}$ \\
\hline BDI_RWA & & 0.047 & 1.000 & 1.000 & \\
\hline BDI_UGA & & 0.162 & 1.000 & 1.000 & \\
\hline KEN_RWA & & 0.983 & 1.000 & & 1.000 \\
\hline KEN_TZA & 5.705 & 645.619 & 6.538 & 5.615 & 0.538 \\
\hline KEN_UGA & & 282.980 & 8.286 & 8.286 & \\
\hline RWA_BDI & & 261.211 & 12.000 & 12.000 & \\
\hline RWA_KEN & & 66.411 & 19.875 & 19.875 & \\
\hline RWA_TZA & 0.714 & 361.961 & 7.857 & 7.000 & 0.286 \\
\hline RWA_UGA & 0.250 & 521.792 & 24.750 & 20.250 & 0.500 \\
\hline TZA_KEN & 2.546 & 433.857 & 8.250 & 7.333 & 0.250 \\
\hline \multicolumn{6}{|l|}{ TZA_RWA } \\
\hline TZA_UGA & & 3.507 & 1.000 & 1.000 & \\
\hline UGA_BDI & & 3.282 & 1.000 & 1.000 & \\
\hline UGA_KEN & 2.000 & 299.696 & 32.667 & 21.000 & 0.333 \\
\hline UGA_RWA & 2.000 & 8.758 & 1.333 & 0.667 & 0.333 \\
\hline UGA_TZA & 1.091 & 36.378 & 3.273 & 3.000 & 0.182 \\
\hline
\end{tabular}

Key: No. - Number, BDI - Burundi, RWA - Rwanda, KEN - Kenya, TZA - Tanzania, UGA - Uganda

\section{Coffee, tea, mate and spices}

Kenya was the largest importer of coffee, tea, mate (a wild shrub for flavoring tea) and spices from other Eastern Africa countries. The significance of tea and coffee is because the country hosts the largest auction house for these commodities in Africa (Error! Not a valid bookmark self-reference.). This maked EAC countries particularly Uganda and Rwanda which produce large quantities of coffee and tea to transport it to the Mombasa (Kenya) auction for sale. The results also reveal that Kenya was the largest exporter of coffee, tea, mate and spices across EAC which is attributed to its reputable high-quality coffee and tea in the world. Tea and coffee accounted 4\% and $30 \%$ of Kenya's recorded total marketed agricultural products (USD 4,469,212,000) in 2017 (KNBS, 2018). However, majority of imports of the products to countries such as Rwanda from Burundi and Uganda from Rwanda could be transitory in the manner that the countries aided in transportation of tea and coffee from producer countries to the main port of Mombasa due to their landlocked nature. 
Table 2: Averages of tariff barriers and trade value of coffee, tea, maté and spices averages (1999-2014)

\begin{tabular}{lrrrrr}
\hline & $\begin{array}{r}\text { Simple Average } \\
\text { (tariff rate) }(\text { in } \\
\text { percentage) }\end{array}$ & $\begin{array}{r}\text { Trade Value } \\
\text { (in thousand } \\
\text { USD) }\end{array}$ & $\begin{array}{r}\text { No. of } \\
\text { Tariff } \\
\text { Lines }\end{array}$ & $\begin{array}{r}\text { No. of Duty- } \\
\text { free Lines }\end{array}$ & $\begin{array}{r}\text { No. of Dutiable }(a d \\
\text { valorem) } \text { Lines }\end{array}$ \\
\hline BDI_KEN & 5.000 & 13.752 & 2.429 & 1.571 & 0.286 \\
BDI_RWA & 8.750 & 0.508 & 1.000 & 0.500 & 0.500 \\
BDI_TZA & 2.000 & 0.328 & 2.200 & 1.800 & 0.400 \\
BDI_UGA & 4.000 & 2.045 & 2.000 & 1.444 & 0.556 \\
KEN_BDI & & 431.132 & 1.667 & 1.667 & 0.167 \\
KEN_RWA & 2.500 & $19,261.211$ & 2.000 & 1.833 & 1.846 \\
KEN_TZA & 4.615 & 2112.866 & 6.615 & 4.308 & 1.286 \\
KEN_UGA & 4.286 & $17,995.786$ & 4.857 & 3.214 & 0.462 \\
RWA_BDI & & 530.086 & 12.429 & 12.429 & 0.143 \\
RWA_KEN & 3.013 & 52.882 & 8.923 & 8.077 & 1.091 \\
RWA_TZA & 0.714 & 1.527 & 2.000 & 1.857 & \\
RWA_UGA & 1.439 & 112.585 & 12.909 & 9.545 & 0.500 \\
TZA_KEN & 2.804 & 296.722 & 8.917 & 7.583 & 0.100 \\
TZA_RWA & & 0.760 & 1.000 & 1.000 & 0.250 \\
TZA_UGA & 0.500 & 3.410 & 1.600 & 1.500 & 0.600 \\
UGA_BDI & 1.250 & 210.726 & 1.250 & 1.000 & 0.250 \\
UGA_KEN & 1.723 & $1,609.324$ & 19.933 & 11.600 & 0.231 \\
UGA_RWA & 1.250 & 518.637 & 1.625 & 1.375 & \\
UGA_TZA & 0.923 & 251.534 & 5.231 & 4.692 & \\
\hline Key:No_-N & & & & \\
\hline
\end{tabular}

Key: No. - Number, BDI - Burundi, RWA - Rwanda, KEN - Kenya, TZA - Tanzania, UGA - Uganda

Majority of tariff rates ranged from between $0.7 \%$ to $5 \%$ across EAC countries apart from Burundi-Rwanda which had the highest rate of $8.75 \%$. Further, the numbers of tariff lines varied across countries ranging from 1 to 20 (Uganda from Kenya). Most countries had at least one ad valorem line with some (Kenya-Rwanda and KenyaTanzania) having approximately two ad valorem lines. The low tariffs suggest that the countries were keen in increasing trade value in these commodities between each other especially to they are auctioned.

\section{Cereals}

Cereals were some of the most traded commodities in the EAC because they are a basic ingredient is the staple foods (Table 3). Kenya was the largest importer of the cereals like maize rice and wheat in the region which could be because of a large population and a decreasing productivity of cereals in the country which could be attributed to climate change. For example, between 1999 and 2014 maize produced in Kenya increased from 2,250,000 tonnes to $3,510,000$ tonnes a $56 \%$ increase but the imports rose from 73,500 tonnes to 458,900 tonnes a $524 \%$ increase (KNBS 2004; KNBS, 2018). The tariff rates for cereals were highest between Kenya and Tanzania with an average of $30.57 \%$ which could be attributed to Kenyan government attempts to protect the local cereals sector. However, they had little effect on imports. In a review of maize policies in Kenya, Mulinge and Witwer (2012) argue that there were no significant import tariffs or non-tariff trade measures that directly affected cereals imports from Uganda and Tanzania between 2005-2007 and 2010.

The results further reveal Uganda to have been the largest exporter of cereals in the region which could be because of favorable weather and high productivity of cereals in the country. Uganda's high productivity for cereals can be indicated by its maize yield which averaged $24.43-100 \mathrm{~kg}$ bags per hectare between 2011 and 2017 while Kenya's averaged 16.35 - 100kg bags per hectare over the same period (FAOStat, 2018). It is also evident that Burundi, Rwanda and Kenya relied heavily on Tanzania and Uganda for cereals. This could be because of the low tariff rates for cereals in EAC region which ranged between $0.3 \%$ (Tanzania from Uganda) to 7\% (Kenya from Uganda) except for high rates of $30 \%$ and $25 \%$ between Kenya-Tanzania and Tanzania-Burundi respectively. The relatively higher tariff rates faced by Uganda and Tanzania could be because cereal imports from these countries 
to Kenya had been subject to a $2.75 \%$ inspection fee according to conditions set in an agreement in the EAC since 2005 (Mulinge and Witwer, 2012).

The cereals tariff lines were highest between Uganda and Kenya (14.2) among them 10 being duty-free lines. The results further reveal that despite their existence, most of the tariff lines (approximately 75\%) were duty-free line with at least one ad valorem line between all the EAC countries. Further, all cereal tariff line between KenyaRwanda and Rwanda-Burundi were duty-free lines. This could be because Kenya faced a growing deficit in maize production, which is a staple cereal, which was mostly met through importing duty-free maize from her neighbors like Uganda and Tanzania at prices below the world market prices (Mulinge and Witwer (2012).

Table 3: Averages of tariff barriers and trade value of cereals averages (1999-2014)

\begin{tabular}{|c|c|c|c|c|c|}
\hline 10 & $\begin{array}{r}\text { Simple Average } \\
\text { (tariff rate)- (in } \\
\text { percentage) }\end{array}$ & $\begin{array}{r}\text { Trade Value } \\
\text { (in thousand } \\
\text { USD) }\end{array}$ & $\begin{array}{l}\text { No. of } \\
\text { Tariff } \\
\text { Lines }\end{array}$ & $\begin{array}{l}\text { No. of Duty- } \\
\text { free Lines }\end{array}$ & $\begin{array}{r}\text { No. of Dutiable } \\
\text { (ad valorem) } \\
\text { Lines }\end{array}$ \\
\hline BDI_KEN & 1.250 & 16.139 & 2.500 & 2.000 & 0.500 \\
\hline BDI_RWA & 3.889 & 221.756 & 2.111 & 1.667 & 0.222 \\
\hline BDI_TZA & 5.303 & $1,999.878$ & 7.455 & 4.727 & 0.909 \\
\hline BDI_UGA & 3.583 & $3,501.658$ & 3.667 & 2.083 & 0.667 \\
\hline KEN_RWA & & 457.997 & 1.000 & 1.000 & \\
\hline KEN_TZA & 30.570 & $5,114.481$ & 8.286 & 6.357 & 0.357 \\
\hline KEN_UGA & 7.055 & $7,385.412$ & 8.133 & 6.067 & 0.333 \\
\hline RWA_BDI & & 61.804 & 7.750 & 7.750 & \\
\hline RWA_KEN & 1.596 & 821.177 & 5.692 & 4.769 & 0.538 \\
\hline RWA_TZA & 5.837 & $3,697.612$ & 6.615 & 4.000 & 0.923 \\
\hline RWA_UGA & 2.179 & $3,817.760$ & 6.769 & 4.308 & 0.615 \\
\hline TZA_BDI & 25.000 & 0.662 & 1.000 & & 1.000 \\
\hline TZA_KEN & 1.278 & $1,311.555$ & 5.583 & 5.167 & 0.167 \\
\hline TZA_UGA & 0.303 & $6,489.409$ & 4.636 & 4.364 & 0.091 \\
\hline UGA_BDI & 1.719 & 45.397 & 2.000 & 2.000 & \\
\hline UGA_KEN & & $2,576.030$ & 14.200 & 9.867 & 0.600 \\
\hline UGA_RWA & 1.556 & 36.088 & 2.333 & 1.667 & 0.667 \\
\hline UGA_TZA & 1.322 & $3,427.589$ & 6.467 & 5.267 & 0.333 \\
\hline
\end{tabular}

Key: No. - Number, BDI - Burundi, RWA - Rwanda, KEN - Kenya, TZA - Tanzania, UGA - Uganda

1.4.2 Proportion of Non-Tariff Barriers (NTBs), GDP and Profit after tax for EAC countries in relation to each other

The proportion of Non-Tariff Barriers (NTBs) was measured in the form of the Burden of Custom Procedures for both the importers and exporters within the EAC (Table 12). It was evident from the results that Rwanda had the highest burden custom procedures as compared to the rest of the countries in the region. That is, while all countries custom burdens ranged between three and four, Rwanda's were between five and six. This tend to influence the amount of trade since most traders were likely to be motivated to trade with countries where burdens were less.

In addition to measuring the proportion of NTBs in the form of the burden of custom procedures, Table 12 recorded the measures of GDP and profit after tax for each country to another. The GDP was a measure of the importing and exporting capacities of each country hence reflect the purchasing power or sales power. The countries' GDP were measured in thousands of US Dollars. The results revealed that Kenya had the highest GDP in the region while Burundi had the least (Table 13). This means that the purchasing power of Kenya was higher than that of the other countries in the region while that of Burundi was the lowest and this could influence the level of trade in the region.

There were differences in the proportions of average profit after tax in each country. While Burundi had the highest profit levels in all countries, Rwanda and Uganda had the lowest. This could be because, Burundi having the lowest GDP might have had cheaper agricultural inputs as compared to the other countries which implies that assuming 
same commodity prices were charged across the region, then they would experience the highest levels of profits. This is also considering that EAC countries had a standard Value Added Tax (VAT) rate of 18\% except Kenya which has a tax rate of $16 \%$ (East African Community [EAC], 2018). On the other hand, the profit after tax proportions for the other countries ranged between $35.39 \%$ to $46.39 \%$. The results also imply that while Burundi traders may have been making supernormal profits after export of agricultural produce, the other countries may have been making relatively normal profits. Burundi's high profits after tax of both imported and exported commodities could be due to low tax rates for the traded products compared to her trading partners. East African Community [EAC], (2018) points out that unlike other EAC countries, Burundi only charged a $10 \%$ tax on imported food products and processed agricultural goods transformed in Burundi and agricultural inputs and $0 \%$ on exports and international transport. Further, Burundi specifies that agricultural and livestock products are exempted from VAT when sold by owners and not withstanding turnover thresholds.

Table 4: The level non-tariff barriers, gross domestic product and profit after tax among EAC countries (1999-2014)

\begin{tabular}{lrrrrrr}
\hline Country & $\begin{array}{r}\text { GDP } \\
\text { Importer }\end{array}$ & $\begin{array}{r}\text { GDP Tax Importer } \\
\text { Exporter }\end{array}$ & $\begin{array}{r}\text { Profit After } \\
\text { (Percent) }\end{array}$ & $\begin{array}{r}\text { Profit After } \\
\text { (Percent) }\end{array}$ & $\begin{array}{r}\text { Burden Custom } \\
\text { Procedures } \\
\text { Importer } \\
\text { (Number) }\end{array}$ & $\begin{array}{r}\text { Burden Custom } \\
\text { Procedures } \\
\text { Exporter } \\
\text { (Number) }\end{array}$ \\
\hline BDI_KEN & 174.382 & 772.262 & 173.440 & 46.390 &. & 3.368 \\
BDI_RWA & 174.382 & 409.397 & 109.915 & 61.618 & 3.368 & 3.928 \\
KEN_UGA & 772.262 & 432.850 & 46.390 & 35.390 & 3.368 & 3.750 \\
RWA_BDI & 409.397 & 174.382 & 36.130 & 173.440 & 5.262 & . \\
RWA_KEN & 409.397 & 772.262 & 36.130 & 45.350 & 5.262 & 3.368 \\
RWA_UGA & 409.397 & 432.850 & 36.130 & 35.390 & 5.262 & 3.750 \\
TZA_BDI & 527.654 & 174.382 & 42.526 & 92.958 & 3.296 & 3.965 \\
UGA_KEN & 432.850 & 772.262 & 35.390 & 46.390 & 3.750 & 3.368 \\
UGA_RWA & 432.850 & 409.397 & 35.390 & 36.130 & 3.750 & 5.262 \\
UGA_TZA & 432.850 & 527.654 & 35.390 & 44.310 & 3.750 & 3.182 \\
Total & 468.049 & 468.049 & 67.132 & 67.132 & 3.749 & 3.791 \\
\hline
\end{tabular}

Key: BDI - Burundi, RWA - Rwanda, KEN - Kenya, TZA - Tanzania, UGA - Uganda

\subsection{Conclusion}

In summary, there is a general decrease in tariff barriers (TBs) and non-tariff barriers (NTBs) in the trade agricultural food commodities in the East African Community (EAC) across the 15 years study period (19992014). Overall, introduction of TBs and NTBs attracted counter measures by the affected trading partner countries. This relatively reduced traded quantities leading to a net welfare loss for both trading partners. Low tariffs for products like coffee suggested that the countries were keen in increasing trade value in the affected commodities. On NTBs, Rwanda had among the least profit after tax of 36 percent compared to an average of 67 percent for all the countries. This was mainly attributed to its higher number of customs procedures which were on average five compared to other countries which had three custom procedures.

\subsection{Recommendation}

The study recommends that the EAC countries can consider reducing NTBs through increasing the number of duty-free and ad-valorem lines, reducing distance and time taken to deliver bulk products. This can be done through investing in common high-speed transport networks like the standard gauge railway and renovating highways connecting these countries especially where the trading partners do not share a common border or involves a landlocked partner. Countries also need to ease their custom procedures to attract more trade with their trading partners. Finally, each country should specialize more on products which it has a comparative advantage in producing and exporting. 


\section{References}

Bezuneh, M., \& Yiheyis, Z. (2014). Has trade liberalization improved food availability in developing countries? An empirical analysis. Journal of economic development, 39(1), 63.

East African Community [EAC] (2018). Value Added Tax. East African Community 2000-2017. Accessed on 20/02/19 from https://www.eac.int/financial/eac-tax-matrices/value-added-tax/162-sector/financial/eactax-matrices

East African Community [EAC] secretariat, (2015). Status of Elimination of Non-tariff Barriers in the East African Community as of December 2015. EAC Secretariat: Arusha, Tanzania

East African Community Secretariat [EACS]. (2014). East African Community Facts and Figures-2014. Arusha, Tanzania: East African Community Secretariat [EACS].

FAOStat (2018). FAOStat Compare Data. Food and Agriculture Organization of the United Nations. http://www.fao.org/faostat/en/\#compare, accessed on 31-12-2018.

Farm Africa. (2016). Report on Market Study of the Aquaculture Market in Kenya. Kenya Market-Led Aquaculture Programme (KMAP). Nairobi: FARM AFRICA 2016:76.

Karugia, J., Wanjiku, J., Nzuma, J., Gbegbelegbe, S., Macharia, E. and Massawe, S. (2009). The Impact of NonTariff Barriers on Maize and Beef Trade in East Africa. Nairobi, Kenya: Regional Strategic Analysis and Knowledge Support System, East and Central Africa (ReSAKSS-ECA).

Kenya National Bureau of Statistics-KNBS (2004). Economic Survey. Nairobi: Government Printer, (17 - 101).

Kenya National Bureau of Statistics-KNBS (2018). Economic Survey. Nairobi: Government Printer, (55-131).

Kenya Trade Organization (2018). Top 50 Flower Exporters in Kenya. Accessed on 28/12/18 from: http://kenyatrade.org/flower-exporters/

Leamer, E. E. (1995). The Heckscher-Ohlin model in theory and practice.

Morrow, P. M. (2010). Ricardian-Heckscher-Ohlin comparative advantage: Theory and evidence. Journal of International Economics, 82(2), 137-151.

Mulinge W. \& Witwer M. (2012). Analysis of incentives and disincentives for maize in Kenya. Technical notes series, Monitoring Africa Food and Agricultural Policies (MAFAP), FAO, Rome.

Nganga, T. K. (2014). Barriers to trade: the case of Kenya1. to global markets, 57.

Nguema, I. E. and Ella, G. A. (2014). Trade Liberalization and Food Security: For a new green Revolution in Africa. Journal of Food Security, 2(2), 42-50.

Okumu, L. and Nyankori, J. O. (2010). Non-Tariff Barriers in EAC Customs Union: Implications for Trade Between Uganda and other EAC Countries. Kampala, Uganda: Economic Policy Research Centre (EPRC).

Ouma, D. O. (2017). Intra-regional agricultural exports in the East African community. African Journal of Economic Review, 5(1), 14-31. 